\title{
Erditze ondorengo gernu-inkontinentzia ekidin edo tratatzeko zoru pelbikoko muskulaturaren entrenamenduaren eraginkortasuna: berrikuspen sistematikoa
}

\author{
Efficacy of pelvic floor musculature training to prevent or treat urinary \\ incontinence after childbirth: systematic review
}

Olatz Amundarain, Ane Hormaetxe, Iraia Bidaurrazaga-Letona, Iratxe Duñabeitia

Medikuntza eta Erizaintza Fakultatea, UPV/EHU, Leioa

iraia.bidaurrazaga@ehu.eus

\section{Laburpena}

Gernu-inkontinentzia nahi gabeko edozein gernu-ihesek sortutako gaitza da. Batez ere emakumeek pairatzen dute eta zoru pelbikoko muskulaturaren disfuntzioaren ondorioz sortzen da, eragile nagusia erditze baginala izanik. Hiru inkontinentzia mota ezberdintzen dira, baina haurdunaldiarekin erlaziorik handiena duena esfortzuak eragindako gernu-inkontinentzia da. Gernu-inkontinentzia tratatzeko hainbat teknika sortu dira. Teknika horien artean ikertuena "Kegel" ariketak diren arren, desadostasuna dago teknika horren eraginkortasunaren inguruan. Hori dela eta, berrikuspen sistematiko honen xedea erditze ondorengo zoru pelbikoko muskulaturaren entrenamenduak, "Kegel" ariketak alegia, gernu-inkontinentzia ekidin edo tratatzeko duen eraginkortasuna aztertzea izan da. Hori lortzeko Pubmed eta PEDro datu-baseetan bilaketa sistematikoa egin zen barneratze- eta kanporatze-irizpideak kontuan izanda. PEDro eskalaren bitartez ikerketen kalitate metodologikoa balioztatu zen. Oro har, berrikuspenean 9 entsegu kliniko aztertu ziren. Ikerlan guztietan emakumeek zoru pelbikoko muskulaturaren entrenamendua egin zuten interbentzio-taldean, gehienetan zortzi astez, eta ebaluazioa interbentzioaren aurretik eta amaitu ondoren egin zitzaien. Orokorrean, fisioterapeutak gainbegiratutako eskola jasotzeaz gain, emakumeek etxean egin zituzten ariketak ia egunero. Hala ere, uzkurketen mota, serie eta errepikapenei dagokienez, protokoloak desberdinak izan ziren ikerketetan. Ikerlan gehienetan emakumeen \% 10ek baino gutxiagok utzi zuten bertan behera tratamendua, erabilitako atxikidura-estrategiei esker. Halaber, errehabilitazioaren ostean, interbentzio-taldeetan gernu-inkontinentzia adierazgarriki gutxitu zen; gainera, emakume batzuen zoru pelbikoko muskulaturaren indar-, erresistentzia- eta uzkurketa-ahalmena ere adierazgarriki hobetu zen. Ondorioz, esan dezakegu zoru pelbikoko muskulaturaren entrenamendua eraginkorra dela gernu-inkontinentzia ekidin edo tratatzeko eta, era berean, bertako muskulatura indartzeko. Hala ere, ezin izan da entrenamenduaren protokolorik egokiena zein den zehaztu.

Gako-hitzak: gernu-inkontinentzia, zoru pelbikoa, entrenamendua, erditzea, Kegel

\section{Abstract}

Urinary incontinence is defined as any involuntary leakage of urine. Women suffer more from urinary incontinence than men. Stress urinary incontinence is the more related to pregnancy. Pelvic floor muscle training (PFMT) or "Kegel" exercises are the most common technique used for the improvement of pelvic floor function. However, there is conflicting scientific evidence regarding its effectiveness for the treatment of urinary incontinence. Therefore, this study aimed to analyze the effectiveness of PFMT or "Kegel" exercises for preventing and treating urinary incontinence. To achieve this aim a systematic review was performed on the Pubmed and PEDro databases. Nine 
articles were found. Methodological quality was assessed using the PEDro scale. In the analyzed studies women in the intervention group performed PFMT. In most studies the duration of the intervention was of eight weeks and the evaluation of the pelvic floor was performed before and after the training. In general, women received one supervised training session and they also practiced exercises on their own. Type of contraction, series and repetition number was heterogeneous among studies. Due to the use of adherence strategies less than 10\% of women left the treatment in most of the studies. Results showed that after PFMT the urinary incontinence in the intervention groups decreased significantly. Also, the strength and resistance of pelvic floor muscles was significantly improved. Therefore, PFMT is effective for preventing and treating urinary incontinence, and to strengthen the pelvic floor musculature. However, it was not possible to determine the best training protocol.

Keywords: urinary incontinence, pelvic floor, training, postpartum, Kegel.

Bidalia: 2019ko ekainaren 17an.

Onartua: 2019ko irailaren 24an.

http://doi.org/10.26876/osagaiz.2.2019.264

\section{Sarrera eta helburuak}

International Continence Society-ren (ICS) arabera, gernu-inkontinentzia edo maskuriaren kontrolgalera nahi gabeko edozein gernu-ihesek sortutako gaitzari deritzo (1). Radzimińska eta lankideek (2) diotenez, gernu-inkontinentziaren arazoa populazio osoaren \% 4-\% 8k pairatzen du, eta, gainera, azken urteetan mundu osoan arazo hau duen pertsona kopurua handitzen ari da. Ez hori bakarrik: osasun-arazoa izateaz gain, gernu-inkontinentziak sortzen duen gastu ekonomikoa izugarria dela aipatu beharra dago (3).

Gure gizarteko helduen artean oso ohikoa den gaitza da, baina, batez ere, emakumeetan agertzen da (4). Zehazki, adin ertain edo nagusiko emakumeen artean gernu-inkontinentziaren prebalentzia \% 30 eta \% 60 artekoa da, hurrenez hurren. Are gehiago, egunero gernu-ihesa pairatzen duten emakumeen kopurua \% 5 eta \% 15 artekoa da, eta kopuru hauek handiagoak dira hirurogeita hamar urtetik gorako emakume instituzionalizatuetan (1).

Orokorrean, gernu-inkontinentzia zoru pelbikoko muskulaturaren disfuntzioaren ondorioz sortzen da (5). Muskulu horiek mikzioan, heste-hustean eta sexu-funtzioan parte hartzen dute, eta haurdunaldian eta erditzean paper garrantzitsua jorratzen dute (5). Literaturaren arabera, sintomarik gabeko emakumeekin alderatuz, zoru pelbikoko disfuntzioak dituzten emakumeek indar gutxiago dute bertako muskulaturan (6). Gainera, antza denez, disfuntzio honen eragile nagusia erditze baginala da. Izan ere, fetuak beheranzko indarra egiten du maskuri, uretra eta pelbiseko muskulaturan, azken horiek kaltetuz (5). Horretaz gain, gestazio eta haurdunaldian zehar zoru pelbikoko egiturek estres-, luzaketa- eta gainkarga-egoerak jasaten dituzte (7). Horregatik, haurdunaldia eta erditze osteko garaia izan ohi dira emakume askok gernu-inkontinentzia pairatzen duten lehen aldia (8). Hain zuzen ere, Espainian haurdunaldiari lotutako gernu-ihesen prebalentzia \% 6 eta \% 43 artekoa da.

Gaitz honen ezaugarriak desberdinak izan daitezke eta ezaugarri horien arabera hiru mota ezberdintzen dira.

Gernu-inkontinentziaren lehenengo mota premiazko gernu-inkontinentzia da. Larrialdiarekin loturiko ustekabeko gernu-ihesak sortutako gaitza da (1). Emakumeek edo gizonek gernua kanporatzeko batbateko gogo jasangaitza sentitzen dute. Inkontinentzia hau maskuriaren gehiegizko aktibazioa dela eta gertatzen da, hau da, maskuriko paretako gihar ildaskatuen nahi gabeko uzkurketen ondorioz, eta egunerokotasuneko edozein gertaerak eragin dezake, hala nola uraren hotsa entzuteak, tenperatura hotzak edota edari hotzak edateak (2). 
Gernu-inkontinentziaren bigarren motari esfortzuak eragindako gernu-inkontinentzia deritzo. International Uroginecological Association (IUGA) eta ICSren arabera, ariketa fisikoa egitean, eztula egitean edo usin egin bitartean gertatzen den nahi gabeko gernu-ihesak sortutako gaitza da (1). Ariketa fisikoak abdomen barneko presioa handitzen du, eta horrek, era berean, maskurian presioa sortzen du, gernu-ihesa eraginez. Hori uretraren sostengua bermatzen duen zoru pelbikoko muskulaturaren ahultasunaren eta esfinter intrintsekoen mekanismoaren kaltearen ondorioz gerta daiteke (2). Hori dela eta, maskuria presio txikiagoz itxiko da eta, horregatik, esfortzu edo ariketa fisikoa egitean ustekabeko gernu-ihesak izango dira. Gernu-inkontinentzia moten artean ohikoena da emakume gazte eta adin ertainekoengan batez ere. Gainera, haurdunaldi eta erditze osteko aldiekin gehien erlazionatzen den gernu-ihes mota da (1). Hain zuzen ere, esfortzuak eragindako gernuinkontinentziak erditzerik gabeko emakumeen \% 31ri eragiten die Espainian eta erditzea izan duten emakumeen \% 42ri. Aldiz, larrialdiko inkontinentzia erditze ondorengo lehen hiru hilabeteetan izateko aukera \% 30ekoa da (8).

Bukatzeko, hirugarren motak gernu-inkontinentzia mistoa du izena. Pertsona batzuek premiazko inkontinentziaren eta esfortzuak eragindako gernu-inkontinentziaren zeinuak eta sintomak pairatzen dituzte, eta gernu-galera hau esfortzuak eta gihar ildaskatuen gehiegizko aktibazioak eraginda gertatzen da (1).

Gernu-inkontinentzia pairatzeko arrisku-faktoreen harira, gernu-ihesa izateko aukera handitu dezakete adinak, menopausiak (estrogenoen jaitsiera dela-eta), funtzionaltasunaren galerak (mugikortasun-galerak, batez ere), galera kognitiboak, lanbideak (zutik denbora luzez egon behar dutenak edo sabel barneko presioa handitzen dutenak), kirolak (step, korrika egin, salto egin...), tabakoak, eta gehiegizko pisua izateak, besteak beste (9). Ez hori bakarrik, haurdunaldiarekin lotuta zehazki, beste arrisku-faktore batzuk ere kontuan hartu behar dira, hala nola haurdunaldi asko izatea, haurrak pisu handia izatea, haurdunaldian pisu asko irabaztea, erditze baginala izatea, erditzean tresneria erabiltzea, erditzean perineoa edota uzkiko esfinterra kaltetzea eta haurdunaldi aurretik edo tartean gernu-inkontinentzia pairatzea (8).

Gaitz honek eragina du emakumeen bizitzaren hainbat aspektutan. Izan ere, emakume hauen bizikalitatea nabarmenki kaltetzen da (3). Askotan autoestimu baxua eta ondoez- eta inpotentziasentsazioa pairatzen dute, haien bizitza pertsonal, sozial eta profesionalaren kalitatea gutxitzen baita. Gainera, jendeak haien egoeraren berri ez izateko, bizimodua aldatzeko beharra sentitzen dute. Horrek eragin kaltegarria du sozializazioan, bakardadea, sexuan aldaketak, depresioa eta estutasuna eraginez, besteak beste. Hori guztia kontuan izanik, gernu-inkontinentzia tratatzeko tratamendurik egokiena bilatzeko garaian emakumearen bizimodua kontuan hartu behar da, hots, ongizate fisiko, psikiko eta soziala bilatu (2).

Aurretik aipatutako guztiak agerian uzten du gernu-inkontinentziaren garrantzia eta emakumeengan duen eragin negatiboa. Hori dela eta, hainbat teknika sortu dira gaitz honi aurre egiteko. Horien artean aurki ditzakegu "Kegel" ariketak, biofeedback-a, pisudun baginako konoak, erresistentziako gailuak (10), sakroko nerbioaren estimulazioa, atzeko nerbio tibialaren estimulazioa, terapia magnetikoak (4), bizimoduaren interbentzioa, maskuri-entrenamendua, inkontinentziaren aurkako tresnak, botiken bidezko interbentzioa edo ebakuntza (8).

Teknika horien guztien artean, zoru pelbikoko muskulaturaren entrenamendua (ZPME), "Kegel" ariketak ere deritzona, izan da gernu-inkontinentzia tratatzeko teknikarik ikertuena eta erabiliena (6).

Zoru pelbikoko muskulaturaren errehabilitazioaren oinarri zientifikoak Arnold Kegel ginekologo estatubatuarrak ezarri zituen. 1950. urtean, 15 urte iraun zuen ikerketa bat burutu zuen, zeinetan gernu-inkontinentziadun pazienteetan zoru pelbikoko entrenamendua erabili zuen (2). Kegelek ondorioztatu zuen muskuluek aktibitatean daudenean geldirik daudenean baino lau aldiz masa gutxiago galtzen dutela. Hori dela eta, muskuluen hondatze anatomiko eta funtzionala hobetzeko metodorik egokiena zela iradoki zuen. Dirudienez, hondatuta dauden muskuluen gune uzkurgarrien aktibitate sistematikoak haien koordinazioa hobetzen du, eta horri esker, abdomen barneko presioa 
handitzen denean, ariketa fisikoa egitean, adibidez, uretra modu egokiagoan uzkurtzen da (2). Kegel ariketen oinarria zoru pelbikoko muskulaturaren borondatezko uzkurketa errepikatuak burutzean datza. Gainera, entrenamendua modu intentsiboan egin ostean, urteetan zehar ariketak egiten jarraitzea gomendatzen da, hau da, ariketak egiteari inoiz ez uztea, horri esker lortutako onurak denboran zehar mantendu ahal izateko (8).

Kegel ariketen inguruan ikerketa anitz burutu diren arren, kontraesan ugari daude. Izan ere, ikerketa batzuek eraginkorrak direla esaten duten bitartean (11-15), beste lan batzuetan haien eragina ez da argi ikusten (16-18). Era berean, ariketak egiteko protokoloak ez daude batere zehaztuta. Nahiz eta ikerketa guztietan pazienteari eskatzen zaion mugimendua goranzko eta barneranzko borondatezko uzkurketa izan, autore batzuek egunean hiru aldiz 8-12 uzkurketa egitea gomendatzen dute, beste batzuek egunean lau aldiz 20 uzkurketa eta badira batzuk egunean 200 uzkurketa egitea gomendatzen dutenak ere (4). Uzkurketaren iraupenari buruzko datuak ere ikerketa batetik bestera aldatu egiten dira, balioak 4 segundotik 30-40 segundora arte doazelarik (19, 20). Entrenamendua egin bitartean emakumeek mantendu beharreko postura ere aldakorra da: jesarrita, belauniko, zutik edo etzanda. Entrenamenduaren iraupenean ere ez dago adostasunik. Iraupen gomendatuena hiru hilabeteko entrenamendua izaten den arren, lan batzuetan astebeteko entrenamendua egiten da, eta beste batzuetan, aldiz, sei hilabetekoa (4).

Ildo berarekin jarraituz, ikerketa batzuek ondoren adierazitako ariketen protokoloak proposatu zituzten. Alde batetik, 2017. urtean Cochranek egin zuen berrikuspen sistematiko batean, zortzi astez, astean hainbat egunetan, pare bat ariketa-serie edo gehiago egin behar zirela aipatzen da. Bestalde, The National Institute for Clinical Excellence-k gainbegiratutako zoru pelbikoko entrenamendua gernu-inkontinentziaren tratamendurako lehen aukera gisa gomendatu zuen, non hiru hilabetez gutxienez zortzi uzkurketa egunean hiru aldiz egin ziren. Aldiz, The International Consultation on Incontinence Committee-ren arabera, esfortzuak eragindako gernu-inkontinentzia zuten emakumeek gainbegiratutako zoru pelbikoko muskulaturaren entrenamendua zortzi-hamabi astez egin behar zuten eta nahikoa hobetu ezean tratamendu osagarri bat egin beharko zuten (4).

Bestalde, literaturaren arabera ez dago argi ariketak gainbegiratuak izan behar diren edo ez, entrenamendu orokorraren iraupenak zenbatekoa izan behar duen eta beste entrenamendu mota batekin bateratu behar den edo bakarrik egin behar den, besteak beste. Ikusitako desadostasunak kontuan hartuta, berrikuspen sistematiko honen helburu nagusia erditze ondorengo zoru pelbikoko muskulaturaren entrenamenduak gernu-inkontinentzia ekidin edo tratatzeko duen eraginkortasuna aztertzea da. Era berean, bigarren mailako helburua izan da emakumeek entrenamendu honekiko izaten duten atxikidura aztertzea eta hori sustatzeko metodoei buruzko behaketa egitea.

\section{Material eta metodoak}

Berrikuspen sistematiko honen ardatz nagusia emakumeek haurdunaldiaren ostean izaten duten gernu-inkontinentzia da. Hori osatzen hasteko, 2018ko urrian Pubmed eta PEDro datu-baseetan jarraian zehaztutako inklusio-irizpideak betetzen zituzten artikuluen bilaketa egin zen. Bilaketa hori egiteko erabilitako gako-hitzak honako hauek izan ziren: "postpartum", "pelvic floor muscle treatment (PFMT)", "urinary incontinence", "pelvic floor", "pelvic floor muscle (PFM)" eta "postnatal".

Honako irizpide hauek betetzen zituzten artikuluak berrikuspen sistematikorako aintzat hartu ziren:

- 2000 eta 2018 urteen artean argitaratutakoak.

- Testu osoa eskuragarri zutenak.

- Gizakiekin, emakumeekin zehazki, egindako lanak.

- Ingelesez edo gaztelaniaz idatzitakoak.

- Ausazko entsegu klinikoak.

- Kontrol-taldea zutenak. 
- Fisioterapiako errehabilitazioa soilik erditu ondoren burutzen zuten ikerketak eta hori egitearen helburu nagusia erditze ondorengo gernu-inkontinentzia ekidin edo tratatzea zenean.

- PEDro eskalan gutxienez 5eko puntuazioa lortzen zutenak. Izan ere, literaturaren arabera, PEDro eskalan 5 baino puntuazio altuagoa lortzen duten ikerketek metodologiaren kalitatea dutela bermatzen da (21).

Irizpide hauek betetzen zituzten artikuluak, aldiz, berrikuspen sistematikotik kanporatuak izan ziren:

- Gida klinikoak, berrikuspen sistematikoak, meta-analisiak, zeharkako ikerketak eta ikerketa pilotuak.

Berrikuspen sistematikorako aintzat hartutako ikerketak PEDro izeneko kalitatea ebaluatzeko tresnaren bidez balioztatu ziren. Eskala hori Verhagen eta laguntzaileek Maastrichteko Unibertsitateko Epidemiologia Sailean sortutako Delphi zerrendan oinarrituta dago (22). Kalitatearen ebaluazioa hamaika mailaz osatuta dago: 2-9 mailak entseguaren barne-baliotasunari buruzkoak dira; 10-11 mailak ikerketaren emaitzak interpretatzeko nahikoa informazio estatistiko duen adierazten dutenak dira, eta 1 maila entseguaren kanpo-baliozkotasunari, generalizazioari edo aplikagarritasunari buruzkoa da. Eskala horren helburua zera da: PEDro datu-basea erabiltzen duen jendeari ausazko entsegu klinikoen (ausazko entsegu kliniko edo entsegu kliniko kontrolatuaren) kalitatea azkar identifikatzen laguntzea. Maila bakoitzari erantzuteko "bai", "ez" edo "ez aplikagarria $(E / A)$ " erabil daitezke. Emaitza guztien baturak entsegu klinikoaren kalitate orokorra adierazten du (Otik 11rako puntuazioarekin) (22).

\section{Emaitzak}

Hasteko, Pubmed datu-basean "Postpartum AND PFMT", "Postpartum AND urinary incontinence", "Postpartum AND pelvic floor" eta "Postpartum AND PFM" hitzak sartzean 1.167 artikulu aurkitu ziren. Ondoren, iragazketa egin zen "free full text", "humans", "clinical trial" eta "female" iragazkien bidez eta artikulu kopurua 7ra gutxitu zen. Jarraian, izenburuak eta laburpenak irakurtzean, artikulu bat kanporatu zen. Azkenik, ikerketak osorik irakurtzean 2 artikulu aukeratu ziren.

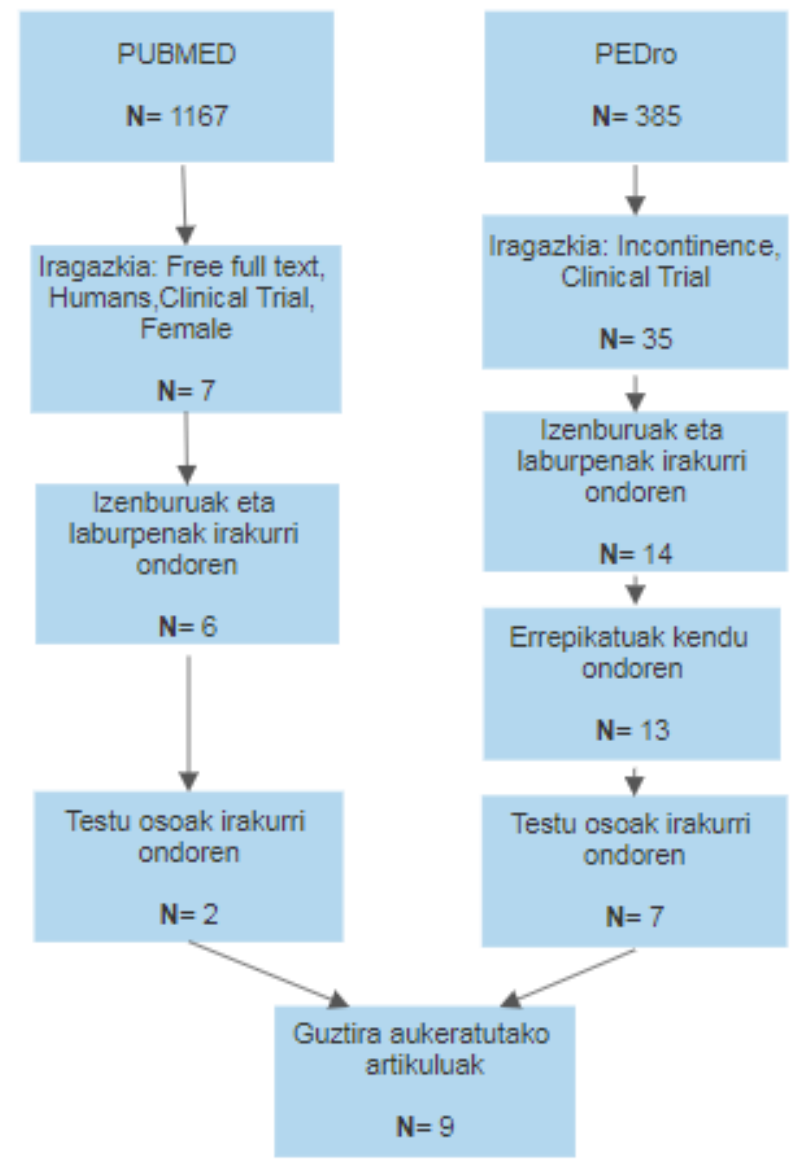

Bestalde, PEDro datu-basean "Postpartum" eta "Postnatal" hitzak bilatu ziren, eta horrela 385 artikulu lortu. Hori egin ostean, "incontinence" eta "clinical trial" iragazkien bidez 39 artikulu eskuratu ziren. Artikuluen izenburuak eta laburpenak irakurritakoan, 14 ikerketa aukeratu ziren, non ikerketa bat Pubmed-en aurkitutako bera zen. Azkenik, testu osoa irakurri ondoren, 7 artikulu aukeratu ziren. $\mathrm{Bi}$ datu-baseetan aurkitutako ikerketen testu osoa irakurtzearekin batera, ikerketak PEDro eskalan gutxienez 5eko puntuazioa lortzea eta 2000. urtetik aurrera argitaratua izatea ziurtatu zen. Beraz, guztira, Pubmed eta PEDro datu-baseen bidez 9 artikulu eskuratu ziren (1. irudia).

1. irudia. Artikuluen bilaketaren fluxu-diagrama. 


\subsection{Ikerketen kalitatea eta ezaugarri orokorrak}

Aukeratutako 9 artikuluak ausazko ikerketa-lanak izan ziren eta haietako zazpik ebaluatzaile itsuak zituzten. Ikerketen metodologiaren kalitateari dagokionez, PEDro eskalaren emaitzak 1. taulan ikus daitezke. Artikuluen artean emaitzarik altuena 9 izan zen eta baxuena 5. Guztien arteko batez bestekoa, berriz, 7,22 izan zen. Horrek adierazten du berrikuspen sistematikoan aintzat hartutako ikerketek metodologia-kalitate egokia zutela.

1. taula. Kalitatearen ebaluazio-zerrendaren puntuazioak.

\begin{tabular}{|c|c|c|c|c|c|c|c|c|c|c|c|c|c|c|}
\hline Zk. & Artikuluak & 1 & 2 & 3 & 4 & 5 & 6 & 7 & 8 & 9 & 10 & 11 & Guztira & $\%$ \\
\hline 18 & Hilde et al., 2013 & + & + & + & + & - & - & + & + & 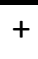 & + & + & $9 / 11$ & $\% 81,81$ \\
\hline 13 & Kim et al., 2012 & + & + & + & + & - & - & + & + & - & + & + & $8 / 11$ & $\% 72,72$ \\
\hline 11 & Chiarelli et al., 2002 & + & + & + & - & - & - & + & + & + & + & + & $8 / 11$ & $\% 72,72$ \\
\hline 17 & Chiarelli et al., 2004 & + & + & + & + & - & - & + & - & + & + & + & $8 / 11$ & $\% 72,72$ \\
\hline 12 & $\begin{array}{l}\text { Dumoulin et al., } \\
2004\end{array}$ & + & + & + & + & - & - & + & + & - & + & + & $8 / 11$ & $\% 72,72$ \\
\hline 23 & $\begin{array}{l}\text { Dumoulin et al., } \\
2013\end{array}$ & + & + & + & + & - & - & + & - & - & + & + & $7 / 11$ & $\% 63,63$ \\
\hline 15 & $\begin{array}{l}\text { Shivkumar et al., } \\
2015\end{array}$ & + & + & - & - & - & - & - & + & + & + & - & $5 / 11$ & $\% 45,45$ \\
\hline 16 & Ahlund et al., 2013 & + & + & + & - & - & - & + & - & - & + & + & $6 / 11$ & $\% 54,54$ \\
\hline 14 & Morkved et al., 2000 & + & + & - & + & - & - & - & + & - & + & + & $6 / 11$ & $\% 54,54$ \\
\hline
\end{tabular}

Plus zeinuak galderak "bai" erantzuna izan duela adierazten du. Minus zeinuak galderak "ez" erantzuna izan duela adierazten du. E/A-k galdera ez dela ikerketan aplikagarria eta ez dela azken puntuazioan kontuan hartzen adierazten du. Ikerketak lortutako puntuazio orokorra eta ehunekoa (\%) azken bi zutabeetan adierazita dago. Zk.: Zenbakia.

\subsection{Lagina}

Ikerketetan parte hartutako laginari buruzko informazioa 2. taulan ikus daiteke: emakume kopurua, haien batez besteko adina, erditze mota eta inkontinentziari buruzko datuak, alegia.

Laginari dagokionez, ikerketetan parte hartutako emakume gehienek erditze baginala izan zuten (11, $13,16-18)$, haietako hirutan amek erditze normala izan zuten $(13,16,18)$ eta beste bitan forzeps edo bentosa bidez erditu ziren $(11,17)$. Gainera, emakume lehenerdiak (lehenengo erditzea izan zutenak) soilik barne hartzen dituzten bi lan daude $(16,18)$. Beste bi lanetan $4.000 \mathrm{~g}$ baino gehiago pisatzen zuen umea izan zuten emakumeek parte hartu zuten $(11,17)$.

\subsection{Gernu-inkontinentzia}

Gernu-inkontinentziaren harira, bost lanetan emakume guztiek inkontinentzia zutela aipatzen da (12, $13,15,16,23)$, beste lauretan, ordea, ez zen zehazten arazo hori zuten emakumeen kopurua $(11,14$, 17, 18). Gernu-inkontinentzia motari dagokionez, emakume gehienek estres motako inkontinentzia zuten, nahiz eta ez den zehazten bi artikuluetako emakumeek zehazki larrialdi edo estres motakoa zuten $(11,17)$. 


\subsection{Interbentzioa}

Emakumeei egindako interbentzioaren iraupena eta ebaluazioari buruzko aipamena 2. taulan ageri da. Erditze ondorengo errehabilitazioarekin hasteko datari erreparatuz gero, ezberdintasunak daude lanen artean. Bi kasutan tratamendua erditze ondorengo 2. egunean hasi zen $(11,17)$, hiru kasutan lehenengo 6.-8. aste bitartean $(13,14,18)$ eta kasu bakarrean, 3. hilabetean (16). Tratamenduaren iraupenari dagokionez, kasu gehienetan 8 aste iraun zuten $(11-15,17)$ eta bi kasutan errehabilitazioak 8 aste baino gehiago iraun zuen $(16,18)$.

\subsection{Ebaluazio-irizpideak eta -tresnak}

Ebaluazioaren harira, emakume guztiak tratamenduarekin hasi aurretik eta amaitzean ebaluatu ziren. Ikerlan gehienetan fisioterapiako errehabilitazioak emakumeengan izandako hobekuntzen neurketa tratamendua amaitu ondoren egin zen $(12-16,18,23)$. Hala ere, bi ikerketatan ebaluazioa interbentzioa amaitu eta sei hilabetera egin zen $(11,17)$. Are gehiago, interbentzioaren emaitzak denboran zehar mantendu ziren edo ez ikusteko, bi lanetan, neurketak interbentzioa bukatu eta berehala egiteaz gain, urtebete eta zazpi urte ondoren berriro egin zituzten $(14,23)$.

Ebaluazioa burutzeko tresna ezberdinak erabili ziren, zeinetan batzuek informazio objektiboa eta besteek informazio subjektiboa baloratzen zuten. Informazio objektiboa lortzeko Pad Test-a $(12,14$, $18,23)$, Oxford eskala $(15,16)$ eta manometroa, dinamometroa eta perineometroa $(16,12,18,13)$ erabili ziren, besteak beste. Aitzitik, informazio subjektiboa lortzeko, "The International Consultation on Incontinence Questionnaire Urinary Incontinence Short Form" (ICIQUISF), "Bristol Female Lower Urinary Tract Symtoms Module" (BFLUTS), "Bristol Female Lower Urinary Tract Symptoms Module" (ICIQ FLUTS) $(13,16,18)$, "Visual Analog Scale" (VAS), "The Incontinence Impact Questionnaire" (IIQ) $(12,15,23)$, "The Urogenital Distress Inventory" (UDI) $(12,23)$ erabili ziren.

\subsection{Interbentzio-protokoloa}

Entrenamenduari erreparatuta (3. taula), emakume guztiek zoru pelbikoko muskulaturaren entrenamendua egin zuten. Dena den, bost ikerlanetan ariketa horiek abdomeneko muskulaturaren ariketekin konbinatu ziren $(11-13,17,23)$, beste ikerlan batean enborraren egonkortze-ariketekin (13), beste batean maskuri-entrenamenduarekin (15) eta, bukatzeko, beste bi lanetan zoru pelbikoaren estimulazio elektrikoarekin konbinatu ziren $(12,23)$.

Zoru pelbikoko muskulaturaren entrenamendurako ez zen protokolo zehatzik erabili. Ariketen serieak, errepikapenak eta egin beharreko uzkurketa motak ikerlan askotan zehaztuta ez zeuden arren, ikerketa batzuetan 8-12 uzkurketako 2-3 serie egin ziren abiadura motelean, jarraian abiadura azkarreko 3-4 uzkurketako 1-2 serie eginez $(14,16,18)$. Uzkurketak maximotik ahalik eta gertuen egitea eskatu zitzaien emakumeei, 6-10 segundoz mantenduz.

Emakumeei entrenamendua etxean egitea gomendatu zitzaien, maiztasuna egunerokoa edo ia egunerokoa izanik (11-14, 17, 18, 23). Ez hori bakarrik; ikerlan batzuetan, emakumeek fisioterapian aditua zen profesional batekin gainbegiratutako klase bat jasotzeko aukera izan zuten. Lau ikerlanetan klase hori astean behin eskaini zen $(12,14,18,24)$; beste batean, astean hiru aldiz (13) eta bi ikerketatan saio bakarra egin zen tratamendu osoan zehar $(11,17)$.

Ikerketetan parte hartutako kontrol-taldeen arteko ezberdintasun nabarmen bat azpimarratu behar da. Izan ere, hiru ikerlanetan emakumeek ez zuten zoru pelbikoko muskulaturaren ariketarik egin (12, $15,23)$. Horren ordez, bizkarreko eta gorputz-adarretako masajea $(12,23)$ edo maskurientrenamendua (15) egin zituzten. Aldiz, beste sei lanetako kontrol-taldeko emakumeek zoru pelbikoko ariketak beren kabuz egiteko aukera izan zuten $(11,13,14,16,17,18)$. Azken talde horretako emakumeek mota ezberdinetako informazioa jaso zuten ariketak egiteko, hala nola informazio-liburuxka $(11,14,16-18)$ edo zoru pelbikoko muskulaturaren uzkurketa egokia egiteko moduari buruzko azalpena $(16,18)$. Bestalde, ikerketa batean interbentzio- eta kontrol-taldeek entrenamendu berdina burutu zuten, baina kontrol-taldeko emakumeek ariketa guztiak beren kabuz egin zituzten fisioterapeutaren ikuskapenik gabe (13). 


\subsection{Atxikidura}

Fisioterapiako errehabilitazioaren atxikidurari eta lortutako emaitzei buruzko datuak 4. taulan daude ikusgai. Errehabilitazioaren atxikidurari dagokionez, ikerketa gehienetan denbora aurrera joan ahala, emakume batzuek tratamendua bertan behera utzi zuten edo ariketak ez zituzten behar bezala egin. Bost ikerketatan, hasierako emakumeen \% 10ek edo gutxiagok utzi zuten tratamendua $(11-14,18)$. Aldiz, beste hirutan emakumeen $\% 10$ galdu zen $(16,17,23)$.

Emakumeek errehabilitazioa bertan behera uztea ekiditeko, ikerlan batzuetan zenbait tresna eta estrategia erabili ziren. Adibidez, hiru entsegu klinikotan entrenamenduen egunerokoa erabili zen emakumeek etxean egindako ariketen maiztasuna idazteko $(13,14,18)$. Ildo berari jarraituz, beste bi ikerlanek atxikidura sustatzeko estrategia gisa ariketak emakumeen ordutegira eta gaitasunetara moldatu zituzten eta gometsak zituen posterraz, bikotearentzako informazio-orriaz eta informazioliburuxkaz baliatu ziren $(11,17)$.

\subsection{Interbentzioen emaitzak}

Emaitzak bi atal ezberdinetan banatzen dira: lehenengo eta bigarren mailako emaitzetan, alegia. Lehenengo mailako emaitzak gernu-inkontinentziaren sendatze edo gutxiagotzearen ingurukoak dira; bigarren mailakoak, ordea, zoru pelbikoko muskulaturaren indar, erresistentzia eta uzkurketari buruzkoak.

Lehenengo mailako emaitzei erreparatuta, azpimarratu behar da erditze ondorengo fisioterapiako errehabilitazioaren ostean interbentzio-taldean gernu-inkontinentzia adierazgarriki gutxitu zela $(p<0.05-0.001)(11-15)$.

Halaber, hiru ikerketatan interbentzio- eta kontrol-taldeen emaitzen artean ez zen ezberdintasun adierazgarririk ikusi $(16,17,18)$. Hala ere, horietariko bi lanetan bi taldeei tratamenduaren hasieran eta amaieran egindako neurketetako emaitzak aztertuz gero, inkontinentzia gutxitu zela aipatu behar da. Hilde eta lankideen (18) ikerketan, tratamenduaren aurretik, emakumeen $\% 44,6 \mathrm{k}$ zuen gernuinkontinentzia. Aldiz, tratamenduaren ostean, \% 36,6k soilik pairatzen zuen. Ahlund eta lankideen (16) ikerketan tratamenduaren hasieran eta amaieran egindako neurketen ezberdintasuna adierazgarria izan zen $(p<0.05)$.

Ildo berari jarraituz, ikerlan batean zoru pelbikoko muskulaturaren entrenamendua egin zuten emakumeen \% 69 kontinentea zela ikusi zen (23).

Bigarren mailako emaitzei dagokienez, ikusi da erditze ondorengo fisioterapiako errehabilitazioaren ostean, interbentzio-taldeko emakumeen zoru pelbikoko muskulaturaren indar-, erresistentzia- eta uzkurketa-ahalmenak nabarmenki hobetu zirela $(p<0.05-0.001)(13-15)$.

Berebat, hiru ikerketatan interbentzio- eta kontrol-taldeen emaitzen artean ez zen ezberdintasun adierazgarririk ikusi $(12,16,18)$. Dena den, bi lanetan bi taldeen tratamenduaren aurreko eta ondorengo neurketak aztertuz muskulaturaren indarra handitu zela ikusi zen $(p<0.05-0.001)(16,18)$. Beste alde batetik, aipatzekoa da ikerlan batean bi interbentzio-taldeen artean ez zela ezberdintasun adierazgarririk egon, ez lehenengo ezta bigarren mailako emaitzetan ere (12).

Bi ikerlanetan, orain arte aipatutako epe motzeko emaitzez gain, epe luzeko emaitzak ere aztertu ziren. Dumoulin eta lankideen (23) ikerketan, zazpi urtera egin zen neurketan bi interbentzio-taldeen gernu-inkontinentziaren maila ebaluatu zen. Gernu-inkontinentziari eta muskuluen indarrari dagokionez, ikusi zen taldeen artean ez zegoela ezberdintasun adierazgarririk, baina interbentzioaren ostean kontinenteak ziren emakumeen \% 63,2k kontinente izaten jarraitzen zuen.

Amaitzeko, aipatzekoa da bi ikerlanetan interbentzio-taldeak maiztasun handiagoz egin zituela zoru pelbikoko muskulaturaren ariketak $(11,17)$. 
2. taula. Aukeratutako ikerketen ezaugarriak $(\mathrm{N}=9)$.

\begin{tabular}{|c|c|c|c|c|c|c|c|c|}
\hline Zk. & Artikulua & $\mathrm{N}$ & Adina & Erditzea & $\begin{array}{l}\text { Inkontinen.mot } \\
\text { a }\end{array}$ & Interbentzioaren iraupena & Ebaluazioa noiz & Ebaluazio-tresnak \\
\hline 18 & $\begin{array}{l}\text { Hilde } \\
\text { et al., } 2013\end{array}$ & 175 & 29,8 & $\begin{array}{l}\text { EB. } \\
\text { Lehenerdiak. }\end{array}$ & Gl ez zehaztua. & $\begin{array}{l}\text { Erditu osteko } 6 .-8 \text {. astetik } \rightarrow \\
\text { 16. astera arte. }\end{array}$ & $\begin{array}{l}\text { Erditu osteko } 6 . \\
\text { astean - } \\
\text { 6. hilean. }\end{array}$ & $\begin{array}{l}\text { ICIQUISF. } \\
\text { Pad test. } \\
\text { Manometroa. }\end{array}$ \\
\hline 13 & $\begin{array}{l}\text { Kim } \\
\text { et al., } 2012\end{array}$ & 20 & 31,72 & EB. & Denek GI. & $\begin{array}{l}\text { Erditu osteko } 6 . \text { astetik } \rightarrow \\
8 \text { aste. }\end{array}$ & $\begin{array}{l}\text { Interbentzioaren } \\
\text { aurretik - ondoren. }\end{array}$ & $\begin{array}{l}\text { BFLUTS. } \\
\text { Perineometroa. }\end{array}$ \\
\hline 11 & $\begin{array}{l}\text { Chiarelli } \\
\text { et al., } 2002\end{array}$ & 720 & $15-44$ & $\begin{array}{l}\text { Forzeps, } \\
\text { bentosa, } 4.000 \\
\text { g } \leq \text { umea. }\end{array}$ & $\begin{array}{l}\text { Gl (estres - } \\
\text { larrialdikoa) ez } \\
\text { zehaztua. }\end{array}$ & $\begin{array}{l}\text { Erditu osteko } 2 \text {. egunetik } \rightarrow \\
8 \text { aste. }\end{array}$ & $\begin{array}{l}\text { 2. egunean }-3 \text {. } \\
\text { hilean. }\end{array}$ & $\begin{array}{l}\text { Maskuri-egunerokoa. } \\
\text { Galdeketa. }\end{array}$ \\
\hline 17 & $\begin{array}{l}\text { Chiarelli } \\
\text { et al., } 2004\end{array}$ & 720 & $15-44$ & $\begin{array}{l}\text { Forzeps, } \\
\text { bentosa, } 4.000 \\
\mathrm{~g} \leq \text { umea. }\end{array}$ & $\begin{array}{l}\text { Gl (estres- } \\
\text { larrialdikoa) ez } \\
\text { zehaztua. }\end{array}$ & $\begin{array}{l}\text { Erditu osteko } 2 \text {. egunetik } \rightarrow \\
8 \text { aste. }\end{array}$ & 12. hilean. & $\begin{array}{l}\text { Maskuri-egunerokoa. } \\
\text { Galdeketa. }\end{array}$ \\
\hline 12 & $\begin{array}{l}\text { Dumoulin } \\
\text { et al., } 2004\end{array}$ & 64 & 36,16 & - & $\begin{array}{l}\text { Denek GI } \\
\text { (estres). }\end{array}$ & 8 aste. & $\begin{array}{l}\text { Interbentzioaren } \\
\text { aurretik - } 9 \text { aste } \\
\text { ondoren. }\end{array}$ & $\begin{array}{l}\text { Pad Test. } \\
\text { VAS, UDI, IIQ. } \\
\text { Dinamometroa. }\end{array}$ \\
\hline 23 & $\begin{array}{l}\text { Dumoulin } \\
\text { et al., } 2013\end{array}$ & 62 & 36,16 & - & Denek Gl. & $\begin{array}{l}8 \text { aste. } \\
7 \text { urtera jarraipena. }\end{array}$ & $\begin{array}{l}\text { Interbentzioaren } \\
\text { aurretik - } 8 \text { aste } \\
-7 \text { urte ondoren. }\end{array}$ & $\begin{array}{l}\text { Pad Test. } \\
\text { VAS, UDI, IIQ. } \\
\text { ZPMaren funtzioa. }\end{array}$ \\
\hline 15 & $\begin{array}{l}\text { Shivkumar } \\
\text { et al., } 2015\end{array}$ & 30 & $20-35$ & - & $\begin{array}{l}\text { Denek GI + } \\
\text { ZPMaren } \\
\text { ahultasuna. }\end{array}$ & 8 aste. & $\begin{array}{l}\text { Interbentzioaren } \\
\text { aurretik - } 8 \text { aste } \\
\text { ondoren. }\end{array}$ & $\begin{array}{l}\text { Oxford eskala. } \\
\text { VAS, IIQ. }\end{array}$ \\
\hline 16 & $\begin{array}{l}\text { Ahlund } \\
\text { et al., } 2013\end{array}$ & 100 & 33 & $\begin{array}{l}\text { EB. } \\
\text { Lehenerdiak. }\end{array}$ & $\begin{array}{l}\text { Denek GI } \\
\text { (estres). }\end{array}$ & $\begin{array}{l}\text { Erditu osteko } 3 \text {. hiletik } \rightarrow \\
6 \text { hil. }\end{array}$ & $\begin{array}{l}\text { 10-16. asteetan } \\
-6 \text { hil ondoren. }\end{array}$ & $\begin{array}{l}\text { Perineometroa. } \\
\text { Oxford eskala. ICIQ FLUTS. }\end{array}$ \\
\hline 14 & $\begin{array}{l}\text { Morkved } \\
\text { et al., } 2000\end{array}$ & 180 & 28 & - & $\begin{array}{l}\text { Gl (estres) ez } \\
\text { zehaztua. }\end{array}$ & $\begin{array}{l}\text { Erditu osteko } 8 \text {. astetik } \rightarrow \\
8 \text { aste } \rightarrow \\
\text { Urtebetera jarraipena. }\end{array}$ & $\begin{array}{l}\text { Interbentzioaren } \\
\text { aurretik - 16. astean } \\
\text { - urtebete ondoren. }\end{array}$ & $\begin{array}{l}\text { Pad test. } \\
\text { Palpazio baginala. } \\
\text { Baloi kateterra. }\end{array}$ \\
\hline
\end{tabular}

Zk.: zenbakia, N: lagina; EB: erditze baginala; GI: gernu-inkontinentzia; ZPM: zoru pelbikoko muskulatura; ICIQUISF: the International Consultation on Incontinence Questionnaire Urinary Incontinence Short Form; BFLUTS: Bristol Female Lower Urinary Tract Symtoms Module; VAS: Visual Analog Scale; UDI: the Urogenital Distress Inventory; IIQ: the Incontinence Impact Questionnaire; ICIQ FLUTS: Bristol Female Lower Urinary Tract Symptoms Module. 
3. taula. Interbentzio-taldearen entrenamenduaren azalpena ( $N=9$ ).

\begin{tabular}{|c|c|c|c|c|c|c|c|}
\hline \multirow{2}{*}{ Zk. } & \multirow{2}{*}{ Artikulua } & \multirow{2}{*}{ Entrenamendu mota } & \multirow{2}{*}{$\begin{array}{l}\text { Serie } \\
\text { ak }\end{array}$} & \multirow{2}{*}{$\begin{array}{l}\text { Errepikapena } \\
\text { k }\end{array}$} & \multirow{2}{*}{ Uzkurketa mota } & \multicolumn{2}{|c|}{ Maiztasuna } \\
\hline & & & & & & $\begin{array}{l}\text { Gainbegiratutako } \\
\text { eskolak }\end{array}$ & Etxeko ariketak \\
\hline 18 & $\begin{array}{l}\text { Hilde } \\
\text { et al., } 2013\end{array}$ & ZPME. & 3 & $8-12$ & $\begin{array}{l}\text { Maximotik } \\
\text { gertu. }\end{array}$ & Astean 1. & Egunero. \\
\hline 13 & $\begin{array}{l}\text { Kim } \\
\text { et al., } 2012\end{array}$ & $\begin{array}{l}\mathrm{ZPME}+\text { abdominalen ariketak + } \\
\text { enborraren egonkortzea (Fit ball). }\end{array}$ & - & 20 & Maximo (10s). & $\begin{array}{l}\text { Astean } 3 \text { (1 ordu). } \\
\text { Ez ikuskatua (K). }\end{array}$ & Egunero. \\
\hline 11 & $\begin{array}{l}\text { Chiarelli } \\
\text { et al., } 2002\end{array}$ & ZPME + abdominalen ariketak. & - & - & - & $\begin{array}{l}\text { Ospitalean, } \\
\text { 8. astean ( } 20-30 \mathrm{~min}) .\end{array}$ & Bai. \\
\hline 17 & $\begin{array}{l}\text { Chiarelli } \\
\text { et al., } 2004\end{array}$ & ZPME + abdominalen ariketak. & - & 6 & - & $\begin{array}{l}\text { Ospitalean, } \\
\text { 8. Astean (20-30 min). }\end{array}$ & Egunean 3 aldiz. \\
\hline 12 & $\begin{array}{l}\text { Dumoulin } \\
\text { et al., } 2004\end{array}$ & $\begin{array}{l}15 \text { min estimulazio elektrikoa + } \\
25 \text { min ZPME (biofeedbackarekin). } \\
15 \text { min estimulazio elektrikoa + } \\
25 \text { min ZPME (biofeedbackarekin) + } \\
30 \text { min abdominalen ariketak. }\end{array}$ & - & - & - & $\begin{array}{l}\text { Astean } 1 . \\
\text { Astean } 1 .\end{array}$ & $\begin{array}{l}\text { Astean } 5 \text { aldiz. } \\
\text { Astean } 5 \text { aldiz. }\end{array}$ \\
\hline 23 & $\begin{array}{l}\text { Dumoulin } \\
\text { et al., } 2013\end{array}$ & $\begin{array}{l}15 \text { min estimulazio elektrikoa + } \\
25 \text { min ZPME. } \\
15 \text { min estimulazio elektrikoa + } \\
25 \text { min ZPME + } 10 \text { min abdominalen } \\
\text { ariketak. }\end{array}$ & - & - & - & $\begin{array}{l}\text { Astean } 1 . \\
\text { Astean } 1 .\end{array}$ & $\begin{array}{l}\text { Egunean } 1, \\
\text { astean } 5 \text { aldiz. } \\
\text { Egunean } 1, \\
\text { astean } 5 \text { aldiz. }\end{array}$ \\
\hline 15 & $\begin{array}{l}\text { Shivkumar } \\
\text { et al., } 2015\end{array}$ & $\begin{array}{l}\text { Maskuri-entrenamendua + ZPME. } \\
\text { Maskuri-entrenamendua (K). }\end{array}$ & - & $\begin{array}{l}\text { Batzuk. } \\
5 \text { gutxienez. }\end{array}$ & $\begin{array}{l}\text { Motel (5 s). } \\
\text { Azkar (10-50 s). }\end{array}$ & $\begin{array}{l}- \\
-\end{array}$ & - \\
\hline 16 & $\begin{array}{l}\text { Ahlund } \\
\text { et al., } 2013\end{array}$ & ZPME. & $\begin{array}{l}1 \\
3\end{array}$ & $\begin{array}{l}3 \text { azkar. } \\
\text { 8-12 motel. }\end{array}$ & Maximo (6s). & $\begin{array}{l}6 \text { astero emaginarekin } \\
\text { errebisioa. }\end{array}$ & Astean 7 aldiz. \\
\hline 14 & $\begin{array}{l}\text { Morkved } \\
\text { et al., } 2000\end{array}$ & ZPME. & $\begin{array}{l}2 \\
2\end{array}$ & $\begin{array}{l}\text { 8-12 motel. } \\
\text { 3-4 azkar. }\end{array}$ & Maximo (6-8 s). & $\begin{array}{l}\text { Astean } 1 \\
\text { (45 min). }\end{array}$ & $\begin{array}{l}\text { Egunero, } \\
6 \text { hilabetez. }\end{array}$ \\
\hline
\end{tabular}

Zk.: zenbakia, ZPME: zoru pelbikoko muskulaturaren entrenamendua; K: kontrol-taldea; s: segundo; Min: minutu. 


\section{4. taula. Ikerketen atxikidurari buruzko informazioa (N=9).}

Zk. Artikulua

18 Hilde

et al., 2013

13 Kim et al., 2012

11 Chiarelli et al., 2002

17 Chiarelli et al., 2004

12 Dumoulin et al., 2004

23 Dumoulin et al., 2013

8 astera: 5 emakume galdu.

7. urtera: 22 emakume galdu.

15 Shivkuma

et al., 2015

16 Ahlund

et al., 2013

14 Morkved et al., 2000

15 emakume galdu.

2 emakume kanporatuak. informazio-liburuxka. informazio-liburuxka.

2 emakume galdu.

$-$

18 emakume galdu.

Entrenamendu egunerokoa.

18 emakume galdu.

\section{Atxikidura}

Entrenamendu egunerokoa, fisioterapeutaren erregistroa.

Ariketak gidatzeko liburuxka, entrenamendu egunerokoa.

Emakumeekin adostasuna, posterra gometsekin, bikotearentzat informazio-orria,

Talde bakoitzeko 22 emakume galdu.

Emakumeekin adostasuna, posterra gometsekin, bikotearentzat informazio-orria,

I. 76 emakume eta K. 75 emakume galdu.

\section{Emaitzak}

GI $\downarrow:$ I-K p=0,569 EA.

M. indar, erresistentzia $\uparrow: I-K E A$.

GI $\downarrow:$ I-K $p<0,05$.

M. uzkurketa $\uparrow: I-K p<0,05$.

GI $\downarrow$ : I-K p=0,044.

ZPME maiztasuna: I-K $p=0,001$.

GI $\downarrow:$ I-K $p=0,340$ EA.

ZPME maiztasuna: $I-K \mathrm{p}=0,039$.

ZPME burututako emakumeek $\rightarrow$ kontinentzia $\uparrow$.

GI $\downarrow$ : Iz-K $p<0,019 ;$ Ia-K $p<0,021$.

M. indarra $\uparrow:$ Iz-la-K EA

Iz-la EA.

8 aste: $\mathbf{G I} \downarrow:$ Iz-la EA.

7.urte: GI $\downarrow$ : Iz-la $p>0,10$ EA.

ZPME burututako emakumeen \% 69 kontinentea.

GI $\downarrow:$ I-K $p=0,0001$.

M. indarra $\uparrow: I-K p=0,0001$.

GI $\downarrow:$ I-K EA.

M. indar, erresistentzia, MVC $\uparrow$ : I-K EA

16 aste+ 1 urte: $\mathbf{G I} \downarrow:$ I-K $p<0,03$.

16 aste -1 urte: $\mathbf{M}$. indarra $\uparrow: I-K p<0,001$.

Emakume kontinenteek $\rightarrow M$. indar $\uparrow p<0,01$.

Zk.: zenbakia, GI: gernu-inkontinentzia; K: kontrol-taldea; I: interbentzio-taldea; ZPME: zoru pelbikoko muskulaturaren entrenamendua; Iz: zoru pelbikoko muskulaturaren entrenamendu taldea; la: zoru pelbiko eta abdomeneko muskulaturaren entrenamendua; EA: ez adierazgarria; M: muskulua; MVC:

maximally voluntary contraction. 


\section{Eztabaida}

Berrikuspen sistematiko honetan ikusi da erditze ondorengo zoru pelbikoko muskulaturaren entrenamenduari esker gernu-inkontinentziaren intzidentzia gutxitzen dela eta bertako muskulaturaren indarra handitzen dela. Emaitza hauek bat datoz aurretik egindako ikerketekin (14, 25). Era berean, American College of Physicians (ACP) erakundearen (26), Urologiako Europar Elkartearen gida klinikoaren (27) eta Cochranen (28) 2018an publikatutako berrikuspen sistematikoaren arabera, emakumeentzat sortutako tratamendu kontserbadoreen artean, lehen aukerako tratamendu gisa gomendatzen da. Beraz, hori guztia ikusita, erditze ondorengo zoru pelbikoko muskulaturaren entrenamendua gernu-inkontinentzia ekidin edota tratatzeko eraginkorra dela esan dezakegu.

\subsection{Lagina}

Laginari dagokionez, emakume gehienek hogei eta berrogei urte artean zituzten. Erditzeei erreparatuz, ikerketetan parte hartu zuten emakume gehienek erditze baginala izan zuten eta, gainera, gehienak lehenerdiak ziren. Hori dela-eta, esan dezakegu zoru pelbikoko muskulaturaren entrenamendua eraginkorra dela erditze baginala izan duten eta lehenerdiak diren emakumeen gernu-inkontinentzia gutxitzeko. Hala ere, eraginkortasuna ez da frogatu beste erditze motak izan dituzten emakumeetan, ezta erditze ugari izan dituzten emakumeetan ere.

\subsection{Gernu-inkontinentzia}

Gernu-inkontinentziaren harira, ikerketen artean aniztasuna dago inkontinentzia pairatzen zuten emakumeen kopuruari eta inkontinentzia motari dagokienez. Ikerlan gehienetan, emakumeek estres motako gernu-inkontinentzia zuten. Inkontinentzia mota hori da haurdunaldiarekin lotura handiena duena (8). Hortaz, zoru pelbikoko muskulaturaren entrenamendua estres motako gernuinkontinentzia gutxitzeko eraginkorra dela ikusi bada ere, baieztapen hori ezin da beste gernuinkontinentzia motetara orokortu.

\subsection{Ebaluazio-irizpideak eta -tresnak}

Ebaluazioari dagokionez, ikerlan gehienetan ebaluazioa interbentzioa egin aurretik eta ondoren egin zen. Horretaz gain, ikerlan batzuetan urte batzuetara berriro neurketak egin ziren. Hori ikusita, esan dezakegu zoru pelbikoko muskulaturaren entrenamenduaren epe laburreko emaitzak aztertzeko komenigarria dela ebaluazioa interbentzioa egiten hasi aurretik eta hori bukatu ondoren egitea. Ez hori bakarrik, entrenamenduaren epe luzeko emaitzak aztertzeko, gomendagarria da interbentzioa amaitu eta hainbat urtetara ere beste neurketa bat egitea. Dumoulin eta lankideek (23) egindako ikerketan, adibidez, zazpi urtera beste neurketa bat egin zuten emaitzak mantendu ziren ikusteko eta emakumeen tratamenduarekiko atxikidura aztertzeko. Izan ere, modu horretan jakin daiteke emakumeek urteetan zehar ariketak egiten jarraitu duten ere.

Ebaluazioarekin jarraituz, ebaluazio-tresnei buruzko aipamena egin behar da. Ikerketetan gehien erabilitako tresnak honako hauek izan ziren: Pad testa, VAS, UDI, IIQ, Oxford eskala, manometroa, perineometroa, dinamometroa eta zenbait galdeketa. Horien artean, gernu-inkontinentzia neurtzeko tresnarik fidagarrienak Pad testa, Oxford eskala, manometroa, perineometroa eta dinamometroa dira, tresna horiek datu objektiboak ematen baitituzte. VAS, UDI, IIQ eta bestelako galdeketek informazio subjektiboa ematen digute, eta informazio objektiboaren osagarri gisa erabilgarriak direla ikusi da. Horrela, tresna subjektiboek orokorrean fidagarritasun, baliozkotasun eta erantzuteko gaitasun-maila egokia badute ere $(12,13,18)$, emakumearen iritzia hartzen dute kontuan, askotan emakumeak berak bere ustearen arabera betetzen duelarik galdeketa eta errealitatea bere nahien arabera alda dezakeelarik. Adibidez, Chiarelli eta lankideen (11) ikerketan, ikusi zen gerta daitekeela emakumeek egin dituzten ariketen maila baino altuagoa egin dutela esatea galdeketari erantzuteko garaian, presio soziala dela eta. Beraz, berrikuspen sistematiko honetan aztertutakoaren arabera, badirudi ikerketen fidagarritasuna hobekien bermatzen duten ebaluazio-tresnak informazio objektiboa ematen dutenak direla. 


\subsection{Interbentzioa}

Zoru pelbikoko muskulaturaren entrenamenduari dagokionez, kasu gehienetan, erditu osteko 6.-8. astean hasi zen entrenamendua. Hain zuzen ere, plazenta egoztetik emakumeen sexu-organoa ohiko egoerara itzultzen den arteko garaiari puerperioa deritzo eta sei aste inguru irauten du. Horregatik, fisioterapiako tratamendua sei eta zortzi aste bitartean hastea egokia dela ikusi da, emakumearen organismoak jasaten duen prozesu fisiologikoa errespetatzen baita.

Ildo beretik jarraituz, ikerketa gehienetan entrenamenduak zortzi aste iraun zuen. Ikerlan ugarik erditze ondorengo garaian emakumeek pairatzen dituzten aldaketak deskribatzen dituzte. Sjömark eta lankideek (29) diotenez, gutxi gorabehera emakumeen herenak erditzea egoera traumatiko bezala deskribatzen dute, eta \% 10ek baino gehiagok jaiotzaren aurrean estres traumatiko larria pairatzen dute. Gainera, erditze ondorengo aldia aldarte-nahasteak sortzeko arrisku handiko garaia izaten da (30). Bestalde, Bäckström eta laguntzaileek (31) diotenez, guraso izatea pertsona askok euren bizitzetan jasaten duten aldaketarik bortitzena da. Hori dela eta, garai estresagarria izan daiteke eta bikoteen harremanaren kalitatea nabarmenki murrizten da. Aipatutako guztia dela medio, emakumeei iraupen luzeko tratamenduak egitea zaila egiten zaiela ikusi da, haien atxikidura txikitzen baita (32). Ondorioz, zortzi asteko entrenamendua aproposa dela uste da.

Zoru pelbikoko muskulaturaren entrenamendua gernu-inkontinentzia gutxitzeko eraginkorra dela ikusi den arren, zoru pelbikoko ariketak soilik eta modu isolatuan aztertzen dituzten ikerketak eskasak dira, gehienetan interbentzio bat baino gehiago konbinatzen baitira. Horrek ondorioak ateratzea zailtzen du, ez baitakigu zein interbentzio izan den eraginkorrena. Aukeratutako ikerketetan, zoru pelbikoko muskulaturaren entrenamenduarekin batera, muskulatura abdominaleko ariketak, enborraren egonkortze-ariketak, estimulazio elektrikoa, biofeedbacka eta maskurientrenamendua erabili ziren. Dumoulin eta lankideen $(12,23)$ ikerketetan, bi interbentzio-taldeetan (zoru pelbikoko muskulaturaren entrenamendua egiten duen taldean eta zoru pelbikoko muskulaturaren entrenamenduaz gain, abdominaletako ariketak egiten dituen taldean) gernuinkontinentzia adierazgarriki gutxitu zela ikusi zen kontrol-taldearekin alderatuta. Aldiz, bi interbentzio-taldeen artean gernu-inkontinentzia gutxiagotzean ez zen aldaketa adierazgarririk egon. Beraz, kasu honetan abdominaletako entrenamendua gehitzeak zoru pelbikoko muskulaturaren entrenamenduarekin lortutako onura ez zuela gehiago hobetu ondorioztatu zen.

Bigarrenik, ikerketa gehienetan entrenamendua egiteko gainbegiratutako klaseak antolatu ziren, maiztasuna gutxienez astean behingoa izanik. Hala ere, klaseen iraupena ez dago zehaztuta. Horrekin batera, ikerlan gehienetan emakumeek ariketak etxean ere egiten zituzten, haien maiztasuna astean gutxienez bost aldiz izanik. Gainera, ikerketa batzuetan ariketak egunean behin baino gehiagotan egin ziren. Hori kontuan izanda, esan dezakegu gernu-inkontinentzia gutxitzeko ezinbestekoak direla bi motatako entrenamenduak: gainbegiratua eta etxekoa. Azken urteotan, fisioterapeutaren gainbegiratzearekin egindako entrenamenduak emaitza hobeak lortzen dituela ikusi da. Izan ere, profesionalaren laguntza eta jarraibideei esker emakumeak entrenamendua ahalik eta hobekien egiten saiatzen dira, horrela, tratamenduaren emaitza arrakastatsuagoak lortzeko aukera emanez (13). Aitzitik, emaitzen arabera argi dago astean egun batean ariketak egitea ez dela nahikoa. Horregatik, emakumeek euren kasa ere ariketak egitea garrantzitsua da. Hori dela eta, fisioterapeutak, berak gidatutako eskoletan, arduratu beharko luke emakumeek etxean ariketak ia egunero egiteko behar duten motibazioa sustatzeaz.

Hariarekin jarraituz, ez dago adostasunik ikerketetan zoru pelbikoko muskulaturaren ariketen serie, errepikapen eta uzkurketen intentsitate, abiadura eta mantendu beharreko iraupenari dagokionez. Horiek horrela, zaila da gai honen inguruko ondorio garbia ateratzea. Antza denez, ariketen errepikapen eta serie gehiago, uzkurketa gehiagorekin eta uzkurketak denboran gehiago mantenduz egiten diren entrenamenduak egokiagoak dira, hau da, entrenamendu intentsiboek emaitza esanguratsuagoak lortzen dituzte (25). Hala ere, berrikuspen sistematiko honetan lortutako emaitzekin ez dugu informazio nahikorik hori baieztatzeko. 


\subsection{Atxikimendua}

Berrikuspen sistematiko honetan atxikiduraren faktoreari ere garrantzia eman diogu. Aurretik aipatu bezala, emakumearentzat erditu osteko garaia bizitzako momentu berezia da, eta, kasu askotan, beren osasunari garrantzia eman beharrean jaioberrira bideratzen dute arreta guztia. Kontinentziaren sustapen-programei buruzko ikerketen arabera, emakumeen \% 52k bertan behera uzten dute erditze ondorengo tratamendua, eta hori gertatzeko arrazoirik ohikoenak ezjakintasuna eta denbora falta izan ohi dira (32). Horren ondorioz, ez da gomendatzen interbentzioa oso luzea izatea, emakumearen motibazioa sustatzea funtsezkoa baita tratamenduarekin jarraitzeko. Aztertutako ikerketen arabera, motibazioa lortzeko atxikidura-tresnak erabil daitezke; esaterako, entrenamenduaren egunerokoa eta gometsak dituzten posterrak erabiltzea, ariketak emakumearen egoerara moldatzea, edota bikotekideari ere informazio-orria eta -liburuxka ematea, errehabilitazioaren parte sentitzeko eta emakumeari laguntzeko. Aztertutako ikerketa gehienetan, emakumeen \% 10ek edo gutxiagok utzi zuen bertan behera tratamendua; beraz, tresna hauek beren funtzioa egoki bete zutela esan daiteke. Hori guztia ikusita, emakumeek tratamendua bertan behera ez uztea ziurtatzeko, bi faktore hartu behar dira kontuan: interbentzioaren fase intentsiboaren iraupena oso luzea ez izatea eta atxikidura-estrategiak erabiltzea. Hemen adibide batzuk aipatu dira, baina bestelako tresnak ere erabil daitezke, betiere emakumearen egoera biologikoa, psikologikoa eta soziala kontuan hartuz eta tratamendua haren beharretara moldatuz.

\subsection{Interbentzioaren emaitzak}

Amaitzeko, emaitza orokorrei dagokienez, ikerketa gehienetan baieztatu da zoru pelbikoko muskulaturaren entrenamendua baliagarria izan zela gernu-inkontinentzia gutxitzeko eta zoru pelbikoko muskuluen indarra eta erresistentzia handitzeko. Kasu gehienetan, interbentzioa egin aurretik eta ondoren egindako ebaluazioan aldaketa adierazgarriak egon zirela ikusi da, eta ez hori bakarrik, interbentzioaren ondoren kontrol- eta interbentzio-taldeei egindako neurketen artean ere aldaketak nabarmendu dira. Beraz, berresten da zoru pelbikoko muskulaturaren entrenamendua baliagarria dela bertako muskulaturaren indarra handitzeko eta, horrek, era berean, gernuinkontinentzia gutxitzen duela. Hala eta guztiz ere, kontuan hartu behar da ikerketa gehienek zoru pelbikoko muskulaturaren entrenamenduaren epe motzeko emaitzak neurtu zituztela, epe luzeko emaitzak neurtu zituzten ikerlanak soilik bi izanik. Horregatik, interbentzio hau epe motzera erabilgarri suertatzen dela esan badezakegu ere, epe luzera sortzen dituen onurak oraindik ez daude erabat argi.

Era berean, berrikuspen sistematiko honek hainbat muga izan ditu. Izan ere, gaiaren inguruko ikerketa gutxi daude. Nahiz eta gai hau emakume askoren bizitzan oso presente egon, kalitate oneko ikerketen bilaketa egitea zaila izan da. Horrekin batera, ez da lortu zoru pelbikoko entrenamenduaren protokolo egokiena zein den zehaztea, ezta haren epe luzeko onurak zeintzuk diren zehaztea ere. Dena den, berrikuspen sistematiko honen puntu indartsuak ere goraipatu behar dira. Ikerlan gutxi barne hartu badira ere, gutxi horiek kalitate onekoak izatea ziurtatu baita.

Azkenik, azpimarratu behar da zoru pelbikoko muskulaturaren entrenamenduaren inguruko ikerketa gehiago behar direla. Ikerketek lagin handikoak izan beharko lukete, erditze mota eta kopuru ezberdina eta gernu-inkontinentzia mota ezberdina duten emakumeetan interbentzioak duen eraginkortasuna alderatuz. Era berean, emakumeak talde ezberdinetan banatu beharko lirateke: kontrol-taldea (fisioterapiako tratamendurik gabe), zoru pelbikoko muskulaturaren entrenamendutaldea eta, adibidez, abdominalen entrenamendu-taldea, bakoitzak interbentzio mota bat isolaturik landuz. Gainera, gomendagarria litzateke zoru pelbikoko muskulaturaren entrenamendu-taldean azpitaldeak egitea, protokolo ezberdinak erabiliz (seriea, errepikapena, intentsitatea, iraupena...). Horretaz gain, emakumeei interbentzioa hasi aurretik eta bukatu ondoren gernu-inkontinentziaren eta muskulaturaren indarraren inguruko datuak neurtu beharko litzaizkieke, tratamenduaren epe motzeko eragina ebaluatzeko, eta, horrekin batera, hainbat urtetara neurketa bera egin beharko litzateke epe luzera emaitzak mantendu diren frogatzeko. Gainera, etorkizuneko ikerketetan, parte hartzaileen atxikidura sustatzeko estrategiak eta tratamenduan zehar fisioterapeutaren presentziak duen garrantzia ere kontuan hartzea interesgarria izango litzateke. 


\section{Ondorioak}

Erditze ondorengo gernu-inkontinentzia gutxitzeko zoru pelbikoko muskulaturaren entrenamenduaren protokolorik egokiena zein den guztiz zehaztu ez den arren, ikusi da zoru pelbikoko muskulaturaren entrenamendua eraginkorra dela gernu-inkontinentzia ekidin edo tratatzeko eta, era berean, bertako muskulatura indartzeko.

\section{Eskerrak eta oharrak}

Lan hau Fisioterapia Graduaren amaierako lanetik eratorria da.

\section{Erreferentzia bibliografikoak}

1. Ayeleke RO, Hay-Smith EJC, Omar MI. Pelvic floor muscle training added to another active treatment versus the same active treatment alone for urinary incontinence in women. Cochrane Database Syst. Rev. 2015 [Kontsulta: 2019-06-24]. The Cochrane Database of Systematic Reviews [Internet]. Hoboken (NJ): John Wiley \& Sons, Ltd. c1999-. Eskuragarri: https://www.cochranelibrary.com/cdsr/doi/10.1002/14651858.CD010551.pub3/abstract

2. Radzimińska A, Strączyńska A, Weber-Rajek M, Styczyńska H, Strojek K, Piekorz Z. The impact of pelvic floor muscle training on the quality of life of women with urinary incontinence: a systematic literature review. Clin Interv Aging 2018; 13: 957-965.

3. Melville JL, Walker E, Katon W, Lentz G, Miller J, Fenner D. Prevalence of comorbid psychiatric illness and its impact on symptom perception, quality of life, and functional status in women with urinary incontinence. Am J Obstet Gynecol 2002; 187(1): 80-7.

4. Price N, Dawood R, Jackson SR. Pelvic floor exercise for urinary incontinence: a systematic literature review. Maturitas. 2010; 67(4): 309-15.

5. Palacios A, Díaz B. Fisioterapia en incontinencia urinaria de embarazo y posparto: una revisión sistemática. Clín Invest Ginecol Obstet. 2016; 43(3): 122-31.

6. Mateus-Vasconcelos ECL, Ribeiro AM, Antônio FI, Brito LG, Ferreira CHJ. Physiotherapy methods to facilitate pelvic floor muscle contraction: A systematic review. Physiother Theory Pract. 2018; 34(6): 420-32.

7. Ruiz de Viñaspre R. Eficacia de la gimnasia abdominal hipopresiva en la rehabilitación del suelo pélvico de las mujeres: revisión sistemática. Actas Urol Esp. 2018; 42(9): 557-66.

8. Woodley SJ, Boyle R, Cody JD, Mørkved S, Hay-Smith EJC. Pelvic floor muscle training for prevention and treatment of urinary and faecal incontinence in antenatal and postnatal women. Cochrane Database Syst. Rev. 2017 [Kontsulta: 2019-06-24]. The Cochrane Database of Systematic Reviews [Internet]. Hoboken (NJ): John Wiley \& Sons, Ltd. c1999-. Eskuragarri: https://www.cochranelibrary.com/cdsr/doi/10.1002/14651858.CD007471.pub3/full

9. Hunskaar S, Arnold EP, Burgio K, Diokno AC, Herzog AR, Mallett VT. Epidemiology and natural history of urinary incontinence. Int Urogynecol J Pelvic Floor Dysfunct. 2000; 11 (5): 301-19.

10. Harvey MA. Pelvic floor exercises during and after pregnancy: a systematic review of their role in preventing pelvic floor dysfunction. J Obstet Gynaecol Can. 2003; 25 (6): 487-98.

11. Chiarelli $\mathrm{P}$, Cockburn J. Promoting urinary continence in women after delivery: randomised controlled trial. BMJ. 2002; 324 (7348): 1241.

12. Dumoulin C, Lemieux MC, Bourbonnais D, Gravel D, Bravo G, Morin M. Physiotherapy for persistent postnatal stress urinary incontinence: a randomized controlled trial: Obstet Gynecol. 2004; 104 (3): 504-10.

13. Kim EY, Kim SY, Oh DW. Pelvic floor muscle exercises utilizing trunk stabilization for treating postpartum urinary incontinence: randomized controlled pilot trial of supervised versus unsupervised training. Clin Rehabil. 2012; 26 (2): 132-41.

14. Morkved S, Bo K. Effect of postpartum pelvic floor muscle training in prevention and treatment of urinary incontinence: a one-year follow up. BJOG. 2000; 107(8): 1022-1028.

15. Shivkumar R, Srivastava N, Gupta J. Effects of Bladder Training and pelvic floor muscle exercise in urinary stress incontinence during postpartum period. Indian J Physiother Occup Ther. 2015; 9(4): 194-98. 
16. Åhlund S, Nordgren B, Wilander EL, Wiklund I, Fridén C. Is home-based pelvic floor muscle training effective in treatment of urinary incontinence after birth in primiparous women? A randomized controlled trial. Acta Obstet Gynecol Scand. 2013; 92 (8): 909-15.

17. Chiarelli P, Murphy B, Cockburn J. Promoting urinary continence in postpartum women: 12month follow-up data from a randomised controlled trial. Int Urogynecol J Pelvic Floor Dysfunct. 2004; 15 (2): 99-105.

18. Hilde G, Stær-Jensen J, Siafarikas F, Ellström Engh M, Bø K. Postpartum pelvic floor muscle training and urinary incontinence: a randomized controlled trial. Obstet Gynecol. 2013; 122 (6): 1231-8.

19. Dumoulin C, Hay-Smith EJC, Mac Habée-Séguin G. Pelvic floor muscle training versus no treatment, or inactive control treatments, for urinary incontinence in women. Cochrane Database Syst. Rev. 2018 [Kontsulta 2019-06-30]. The Cochrane Database of Systematic Reviews [Internet]. Hoboken (NJ): John Wiley \& Sons, Ltd. c1999-. Eskuragarri: https://www.cochranelibrary.com/cdsr/doi/10.1002/14651858.CD005654.pub4/full?cookiesEnabled

20. Peschers U, Vodusek D, Fanger G, Schaer G, Delancey J, Schussler B. Pelvic muscle activity in nulliparous volunteers. Neurourol. Urodyn. 2001; 20: 269-75.

21. Moseley AM, Herbert RD, Sherrington C, Maher CG. Evidence for physiotherapy practice: A survey of the Physiotherapy Evidence Database (PEDro). Aust J of Physiother. 2002; 48(1): 43-9.

22. Verhagen AP, de Vet HC, de Bie RA, Kessels AG, Boers M, Bouter LM, Knipschild PG. The Delphi list: a criteria list for quality assessment of randomized clinical trials for conducting systematic reviews developed by Delphi consensus. J Clin Epidemiol. 1998; 51(12): 1235-41.

23. Dumoulin C, Martin C, Elliott V, Bourbonnais D, Morin M, Lemieux MC, Gauthier R. Randomized controlled trial of physiotherapy for postpartum stress incontinence: 7-year follow-up. Neurourol Urodyn. 2013; 32 (5): 449-54.

24. Burns PB, Rohrich RJ, Chung KC. The levels of evidence and their role in evidence-based medicine. Plast Reconstr Surg. 2011; 128 (1): 305-10.

25. Saboia DM, Bezerra K, Vasconcelos JA, Bezerra LRPS, Oriá MOB, Vasconcelos CTM. The effectiveness of post-partum interventions to prevent urinary incontinence: a systematic review. Rev Bras Enferm. 2018; 71(suppl 3): 1460-68.

26. Qaseem A, Dallas P, Forciea MA, Starkey M, Denberg TD, Shekelle P. Nonsurgical Management of Urinary Incontinence in Women: A Clinical Practice Guideline fron the American College of Physicians. Ann Intern Med. 2014; 61 (6): 429-40.

27. Lucas MG, Bosch RJL, Burkhard FC, Cruz F, Madden TB, Nambiar AK, Neisius A, de Ridder DJMK, Tubaro A, Turner WH, Pickard RS. Guía clínica de la Asociación Europea de Urología sobre la evaluación y el tratamiento no quirúrgico de la incontinencia urinaria. Actas Urol Esp. 2013; 37 (4): 199-213.

28. Dumoulin C, Cacciari LP, Hay-Smith EJC. Pelvic floor muscle training versus no treatment, or inactive control treatments, for urinary incontinence in women. Cochrane Database Syst. Rev. 2018 [Kontsulta: 2019-09-13]. The Cochrane Database of Systematic Reviews [Internet]. Hoboken (NJ): John Wiley \& Sons, Ltd. c1999-. Eskuragarri: https://www.cochranelibrary.com/cdsr/doi/10.1002/14651858.CD005654.pub4/abstract

29. Sjömark J,Parling $T$, Jonsson $M$, Larsson $M$, Skoog Svanberg A. A longitudinal, multi-centre, superiority, randomized controlled trial of internet-based cognitive behavioural therapy (iCBT) versus treatment-as-usual (TAU) for negative experiences and posttraumatic stress following childbirth: the JUNO study protocol. BMC Pregnancy Childbirth. 2018; 18(1): 387.

30. Toru T, Chemir F, Anand S. Magnitude of postpartum depression and associated factors among women in Mizan Aman town, Bench Maji zone, Southwest Ethiopia. BMC Pregnancy Childbirth. 2018; 18(1): 442.

31. Bäckström C, Kåreholt I, Thorstensson S, Golsäter M, Mårtensson LB. Quality of couple relationship among first-time mothers and partners, during pregnancy and the first six months of parenthood. Sex Reprod Healthc. 2018; 17: 56-64.

32. Chiarelli $P$, Murphy B, Cockburn J. Acceptability of a urinary continence promotion programme to women in postpartum. BJOG. 2003; 110 (2): 188-196. 